\author{
Agnieszka Małkowska \\ Małgorzata Uhruska \\ Agnieszka Żak
}

\title{
Inwestycje prorozwojowe gmin w kontekście koncepcji odpowiedzialnego inwestowania*
}

\section{Streszczenie}

Polityka inwestycyjna gmin jest częścią polityki rozwoju lokalnego. Jej cele ukierunkowane są na zaspokajanie potrzeb społeczności lokalnej, m.in. w zakresie dostępu do infrastruktury technicznej i społecznej, jak również na budowanie potencjału gospodarczego obszaru. Mimo że polityka inwestycyjna gmin koncentruje się na potrzebach społeczności lokalnej, nie oznacza to, że sposób jej realizacji odpowiada zasadom inwestowania społecznie odpowiedzialnego.

Artykuł ma charakter koncepcyjny i stanowi przyczynek do dalszych badań w tej dziedzinie. Jego celem jest wskazanie podstawowych obszarów społecznej odpowiedzialności

Agnieszka Małkowska, Uniwersytet Ekonomiczny w Krakowie, Wydział Ekonomii i Stosunków Międzynarodowych, Katedra Ekonomiki Nieruchomości i Procesu Inwestycyjnego, ul. Rakowicka 27, 31-510 Kraków, e-mail: malkowsa@uek.krakow.pl

Małgorzata Uhruska, Uniwersytet Ekonomiczny w Krakowie, Wydział Ekonomii i Stosunków Międzynarodowych, Katedra Ekonomiki Nieruchomości i Procesu Inwestycyjnego, ul. Rakowicka 27, 31-510 Kraków, e-mail: uhruskam@uek.krakow.pl

Agnieszka Żak, Uniwersytet Ekonomiczny w Krakowie, Wydział Ekonomii i Stosunków Międzynarodowych, Katedra Zarządzania Międzynarodowego, ul. Rakowicka 27, 31-510 Kraków, e-mail: agnieszka.zak@uek.krakow.pl

* Artykuł powstał w wyniku realizacji projektu badawczego finansowanego ze środków przyznanych Wydziałowi Ekonomii i Stosunków Międzynarodowych Uniwersytetu Ekonomicznego w Krakowie w ramach dotacji na utrzymanie potencjału badawczego. 
gmin w działalności inwestycyjnej zarówno w odniesieniu do własnej polityki inwestycyjnej, jak i do innych podmiotów realizujących inwestycje na obszarze gminy. W pracy wyszczególniono obszary aktywności gminy w procesie odpowiedzialnego inwestowania dotyczące m.in.: badania i hierarchizacji potrzeb inwestycyjnych, definiowania dokumentów strategicznych, określania kryteriów wyboru inwestycji oraz standardów ich realizacji i oceny. Przedstawiono główne przyczyny i konsekwencje inwestycyjnych działań gminy realizowanych niezgodnie z ideą odpowiedzialnego inwestowania.

Słowa kluczowe: zrównoważony rozwój, inwestycje społecznie odpowiedzialne, inwestycje publiczne, infrastruktura, rozwój lokalny, gmina.

Klasyfikacja JEL: H41, H70, O1, O2, Q01, R11.

\section{Wprowadzenie}

„Interes, który nic poza pieniędzmi nie przynosi, jest złym interesem” - te słowa przypisywane Henry’emu Fordowi mogą tłumaczyć rosnące zainteresowanie wielu organizacji i inwestorów indywidualnych uwzględnianiem w swych działaniach aspektów nie tylko ekonomicznych, ale również etycznych, społecznych czy ekologicznych. Świadomość i pogodzenie tych trzech obszarów stanowi o zrównoważonym rozwoju. Jest to koncepcja, która łączy rozwój gospodarczy i sprawiedliwy podział korzyści z niego wynikających z rozwojem społecznym, ochroną środowiska i racjonalną gospodarką zasobami naturalnymi, tak by mogły z nich korzystać także przyszłe pokolenia. Realizacja tej idei to zatem poszukiwanie takich rozwiązań dla działalności gospodarczej, które są społecznie odpowiedzialne, ekologicznie przyjazne i jednocześnie ekonomicznie wartościowe [Rok 2008]. Strategia zrównoważonego rozwoju jest podstawą odpowiedzialności w nowoczesnym biznesie. Mimo że pojęcia zrównoważonego rozwoju i odpowiedzialności społecznej biznesu (CSR) ${ }^{1}$ często używane są zamiennie, jasno rozróżnia je opracowana w 2010 r. norma społecznej odpowiedzialności ISO 26000 Guidance on social responsibility (zob. http://www.odpowiedzialnafirma. $\mathrm{pl} / \mathrm{o}-\mathrm{csr} /$ iso-26000). Norma ta jest przewodnikiem dla organizacji w zakresie stosowania zasad odpowiedzialności społecznej i środowiskowej. Systematyzuje wiedzę na temat szeroko rozumianej społecznej odpowiedzialności biznesu i jest

${ }^{1}$ Powszechnie używany akronim CSR najczęściej rozwijany jest jako corporate social responsibility lub company social responsibility. Obecnie spotyka się także rozwinięcie corporate stakeholder responsibility (odpowiedzialność biznesu wobec interesariuszy) lub corporate sustainability and responsibility (zrównoważony i odpowiedzialny biznes). Wskazuje to na różne postrzeganie tej idei oraz tłumaczy wielość definicji występujących w literaturze przedmiotu. W wielu źródłach zrównoważony rozwój i CSR są traktowane jako pojęcia synonimiczne lub należące do tego samego obszaru zagadnień. W ostatnich latach koncepcje te stają się w coraz większym stopniu ze sobą powiązane. Zob. [Jonker, Rudnicka i Reichel 2011]. 
adresowana do różnych typów organizacji - zarówno biznesowych, jak i sektora publicznego czy organizacji pozarządowych - z zaznaczeniem jednak, że celem normy nie jest zastępowanie, zmienianie czy modyfikowanie obowiązków organów państwowych [Ślęzak-Gładzik 2013], niezależnie od ich wielkości oraz miejsca prowadzenia działalności.

Zgodnie z normą ISO 26000 zrównoważony rozwój to doktryna ekonomii politycznej zakładająca dążenie do jakości życia na poziomie, na jaki pozwala obecny rozwój cywilizacyjny. Koncepcja ta zakłada, że ludzie, a w szczególności przedstawiciele biznesu, $w$ ramach prowadzonej przez siebie działalności powinni brać pod uwagę wyzwania społeczne, środowiskowe i ekonomiczne. Jej realizacja $\mathrm{z}$ jednej strony jest wymogiem czasu, z drugiej zaś świadczy o odpowiedzialności za przyszłe pokolenia. Z kolei społeczna odpowiedzialność biznesu skupia się na organizacji, nie na świecie. Jest jednak ściśle związana ze zrównoważonym rozwojem, ponieważ celem CSR powinien być wkład do tej idei. Społeczna odpowiedzialność biznesu to spojrzenie mikro na strategię prowadzenia biznesu, która powinna być skutecznym mechanizmem tworzącym wartość dodaną poprzez stymulowanie innowacyjności i budowanie przewagi konkurencyjnej.

Jak pisze A. Lewicka-Strzałecka [2006], społeczna odpowiedzialność biznesu jest odpowiedzialnością szczególnego rodzaju systemu. Tworzą go zarówno podmioty działające na rynku, jak i łączące je relacje oraz wykształcone w procesie tego działania instytucje. System ten jest sterowany siłami rynkowymi i nie posiada jednego, wspólnego ośrodka kierowniczego, co sprawia, że na jego odpowiedzialność składa się odpowiedzialność poszczególnych przedsiębiorstw. Uwzględniając jednak wpływ na funkcjonowanie biznesu szeroko pojętego otoczenia (m.in. politycznego czy prawno-administracyjnego), słuszne wydaje się założenie, że system ten współtworzą nie tylko przedsiębiorstwa, ale również jednostki samorządu terytorialnego (co wyraźnie widać np. w ramach partnerstwa publiczno-prywatnego). Warto zauważyć, że obszary społecznej odpowiedzialności biznesu według wspomnianej powyżej normy (ład korporacyjny i praktyki zarządcze, prawa człowieka, miejsce pracy, ochrona środowiska, relacje z konsumentami, klientami oraz kontrahentami, praktyki w łańcuchu dostaw oraz zaangażowanie społeczne) mogą odnosić się do gmin i ich odpowiedzialności wobec interesariuszy oraz powinny być uwzględniane przy ustalaniu priorytetów działalności tych jednostek. Z kolei pomocne i uniwersalne narzędzia wypracowane w ramach koncepcji CSR mogą być wykorzystywane także poza sferą biznesu - zarówno przez samorządy, jak i organizacje obywatelskie.

Polityka inwestycyjna gmin jest kluczowym elementem polityki rozwoju lokalnego i powinna być podporządkowana zasadom zrównoważonego rozwoju. Gmina poprzez jej kształtowanie, a następnie realizację określonych projektów inwestycyjnych z jednej strony zaspokaja potrzeby społeczności lokalnej, z drugiej 
stwarza warunki do prowadzenia działalności gospodarczej i inwestycyjnej różnych podmiotów, w wyniku czego tworzy się potencjał rozwojowy obszaru. Określenie priorytetów i celów inwestycyjnych oraz sposób ich realizowania przez gminy można oceniać przez pryzmat zasad inwestowania społecznie odpowiedzialnego. Brak na ten temat dyskusji w literaturze może wynikać z założenia, że społeczna odpowiedzialność jest wpisana w istotę działalności jednostek samorządu terytorialnego. Jednak wiele przykładów już zrealizowanych inwestycji gminnych, które nie przyniosły spodziewanych korzyści, a nawet pociągnęły za sobą negatywne skutki odczuwane przez społeczność lokalną, skłoniło autorów do przyjrzenia się temu zagadnieniu.

Celem artykułu jest wskazanie głównych obszarów aktywności gminy w procesie odpowiedzialnego inwestowania, zarówno w odniesieniu do własnej polityki inwestycyjnej, jak i do innych podmiotów realizujących inwestycje na obszarze gminy. Przedstawiono główne przyczyny i konsekwencje inwestycyjnych działań gminy realizowanych niezgodnie z ideą odpowiedzialnego inwestowania. Artykuł ma charakter koncepcyjny, a jego zadaniem jest zarysowanie obszaru problemowego, jakim jest implementacja koncepcji odpowiedzialnego inwestowania do działalności sektora publicznego na szczeblu lokalnym.

\section{Inwestowanie odpowiedzialne społecznie - zarys koncepcji}

W kontekście ogólnych rozważań na temat społecznej odpowiedzialności biznesu i zrównoważonego rozwoju należy zauważyć zwiększone zainteresowanie zjawiskiem kompensacji w różnych obszarach działalności. Stwierdzenie to stanowi punkt wyjścia do analizy zagadnień związanych ze zrównoważonymi inwestycjami.

Inwestycje społecznie odpowiedzialne (socially responsible investment, SRI) powstały w odpowiedzi na zapotrzebowanie inwestorów chcących łączyć korzyści materialne z realizacją wyznawanych wartości. Początków inwestycji społecznie odpowiedzialnych można szukać w Wielkiej Brytanii, gdzie w latach 20. XX w. Kościół metodystów starał się kierować wartościami w swoich przedsięwzięciach inwestycyjnych i odrzucał te, które stały z nimi w sprzeczności. Pomimo że zainteresowanie społecznie odpowiedzialnymi inwestycjami pojawiło się na początku ubiegłego wieku, to ich decydujący rozwój można odnotować dopiero w latach 90. XX w. [Lewicka-Strzałecka 2006, s. 39].

Podobnie jak w przypadku pojęcia zrównoważonego rozwoju czy społecznej odpowiedzialności biznesu inwestowanie społecznie odpowiedzialne nie jest pojęciem jednoznacznym i nie jest łatwo je zdefiniować (zob. [Odpowiedzialne inwestowanie 2017]). Termin „odpowiedzialne inwestowanie” jest często używany 
zamiennie z terminami ,etyczne inwestowanie”, ,zrównoważone inwestowanie”, ,zielone inwestowanie” lub ,inwestowanie społecznie odpowiedzialne” (zob. [Marcinek 2012]). Odpowiedzialne inwestowanie to strategia inwestowania środków, indywidualnych lub należących do instytucji, która w równym stopniu dąży do maksymalizacji zysku, jak i osiągania określonych celów społecznych i uwzględniania potrzeby rozwijania się w zrównoważony sposób [Wpływ czynników... 2016]. Geneza SRI ma odbicie w definicji, w której odpowiedzialne inwestowanie postrzega się jako proces uzgadniania osobistych lub organizacyjnych decyzji inwestycyjnych z wartościami osobistymi lub wartościami organizacji i sprawami społecznymi [Jonker, Rudnicka i Reichel 2011]. Tak zdefiniowane inwestycje społeczne ${ }^{2}$ (community investments) lub społecznie odpowiedzialne inwestowanie przyczyniają się zarówno do osiągania przez przedsiębiorstwa zwrotu z rynku, jak i do poprawy warunków społecznych i środowiskowych.

Definicji, w których podejmuje się próbę uchwycenia tego tematu, jest wiele, ale nawet jeśli używane są różne terminy, dwa elementy pozostają stałe: długoterminowe budowanie wartości oraz oparcie na kryteriach związanych ze środowiskiem, społeczeństwem i ładem korporacyjnym, czyli ESG (environment, social, governance).

Inwestowanie odpowiedzialne społecznie to inwestowanie w spółki prowadzące działalność odpowiedzialną społecznie (CSR). Jak podkreśla A. Duliniec [2015], CSR i SRI to „dwie strony tego samego medalu” - aktywność gospodarcza odpowiedzialna społecznie może być rozpatrywana z jednej strony z punktu widzenia przedsiębiorstw oraz ich zarządów, a z drugiej strony - z punktu widzenia inwestorów na rynku kapitałowym. Idea społecznie odpowiedzialnego inwestowania zakłada równorzędne spełnianie wymogów ekonomicznych i etycznych. Inwestycje społecznie odpowiedzialne, podobnie jak działania CSR, powinny stanowić nierozłączną część długofalowej strategii przedsiębiorstwa. Dążenie do osiągnięcia pozycji lidera oparte na strategii CSR i stosowanie zasad odpowiedzialnego inwestowania mogą być korzystne dla firm z uwagi na budowanie pozytywnych stosunków z lokalnymi władzami, otoczeniem gospodarczym, klientami i pracownikami [Brodowicz 2014].

Inwestorzy społecznie odpowiedzialni w swoich decyzjach inwestycyjnych uwzględniają oprócz czynników finansowych również aspekty pozafinansowe. Wyróżniają oni te przedsiębiorstwa, które stosują praktyki z zakresu zrównoważonego rozwoju. Wśród czynników środowiskowych, które mogą mieć wpływ na podjęcie działań inwestycyjnych, są te związane z ograniczaniem skali negatywnego oddziaływania na środowisko - np. zużycie energii, emisja gazów

${ }^{2}$ Inwestycja społeczna oznacza taką inwestycję, dzięki której próbuje się osiągać wartości zarówno finansowe, jak i społeczne oraz środowiskowe. Można wyróżnić dwie kategorie inwestycji społecznych: inwestycje społecznie odpowiedzialne i inwestycje w społeczność lokalną. 
cieplarnianych, zarządzanie neutralnymi zasobami czy bioróżnorodność. Wśród aspektów społecznych mogą znaleźć się m.in. ochrona praw człowieka, stosunki pracy, bezpieczeństwo i zdrowie czy relacje ze społecznościami. Z kolei czynniki nadzoru korporacyjnego to np. czynniki związane ze strukturą organizacji, przestrzeganiem praw akcjonariuszy czy przejrzystym ładem organizacyjnym [Wolska i Czerwonka 2013].

Inwestycje SRI występują w różnych klasach aktywów. W ostatnich latach obok najprężniej rozwijających się inwestycji społecznie odpowiedzialnych w obszarze inwestycji w aktywa finansowe obserwuje się równie szybki rozwój inwestycji rzeczowych (np. w nieruchomości) oraz innych, np. inwestycji w kapitał ludzki.

Podsumowując, społecznie odpowiedzialne inwestowanie to strategia uwzględniania - oprócz klasycznej stopy zwrotu z funduszy inwestycyjnych - także celów społecznych, etycznych i ekologicznych. Dotyczy to zarówno finansowych potrzeb inwestora, jak i wpływu inwestycji na społeczeństwo. Jest to zatem wielowymiarowe rozumienie finansowych praktyk inwestycyjnych jako tych, które działają na korzyść szerszych i długoterminowych potrzeb wielu interesariuszy.

\section{Inwestycje gmin jako narzędzie polityki rozwoju lokalnego}

Problematyka działalności inwestycyjnej gmin oraz ich skutków społeczno-ekonomicznych mieści się w szerokim obszarze rozważań nad inwestycjami publicznymi i ich związkiem z rozwojem i wzrostem gospodarczym. Samo pojęcie inwestycji publicznych można ogólnie odnieść do nakładów inwestycyjnych ponoszonych na infrastrukturę rzeczową (physical infrastructure), taką jak drogi, budynki użyteczności publicznej itp. oraz na infrastrukturę ,miękką” (soft infrastructure), czyli np. rozwój kapitału ludzkiego, wspieranie innowacji, badań i rozwoju, których produktywne wykorzystanie przekracza jeden rok [Recommendation of the Council... 2014, s. 4]. Inwestycji publicznych nie można utożsamiać jedynie z tymi, które zostały bezpośrednio czy też w całości sfinansowane ze środków publicznych. Obecnie coraz powszechniej wykorzystywanym modelem realizacji przedsięwzięć o charakterze publicznym, szczególnie w zakresie inwestycji rzeczowych, jest partnerstwo publiczno-prywatne, gdzie rola partnera publicznego nie musi wiązać się z ponoszeniem nakładów finansowych w procesie inwestowania, które często scedowane są na stronę prywatną.

Większość inwestycji publicznych jest podejmowanych w obszarach kluczowych dla przyszłego wzrostu gospodarczego, zrównoważonego rozwoju oraz jakości życia społecznego. Związek pomiędzy inwestycjami publicznymi a rozwojem gospodarczym stał się istotnym przedmiotem badań zarówno w literaturze naukowej, jak i w ramach analiz prowadzonych przez takie instytucje, jak Bank 
Światowy czy OECD. Znaczenie, jakie przypisuje się inwestycjom publicznym w gospodarce, ma źródło w teoriach i koncepcjach rozwoju i wzrostu gospodarczego, w których istotną rolę odgrywa infrastruktura. Należą do nich m.in.: model Harroda-Domara, model neoklasyczny Solowa, teorie wzrostu endogenicznego Romera, Barro, Lucasa, koncepcja „wielkiego pchnięcia” Rosensteina-Rodana [Ratajczak 2000, s. 100-101]. Dyskusję w środowisku naukowym nad problemem wpływu inwestycji publicznych na gospodarkę ożywił D. Aschauer swoimi badaniami i publikacjami na ten temat (zob. np. [Aschauer 1989a, 1989b, 1990a, 1990b, 1990c]). Ponadto zagadnienie to było podejmowane przez wielu innych badaczy, którzy często skupiali uwagę na inwestycjach infrastrukturalnych w kontekście ich oddziaływania na gospodarkę lokalną i regionalną (zob. np. [Munnell i Cook 1990, Duffy-Deno i Randall 1991, Munnell 1992, Kassides 1993, Rives i Heaney 1995, Calderón i Servén 2004, Gil i Beckman 2009]). W literaturze polskiej związki infrastruktury z gospodarką omawiał m.in. M. Ratajczak [2000].

Wpływ infrastruktury na gospodarkę rozważany jest na płaszczyźnie makroi mikroekonomii, najczęściej w odniesieniu do produktywności, skali i kosztów produkcji, decyzji lokalizacyjnych, skłonności do podejmowania inwestycji prywatnych, stopy zwrotu z inwestycji prywatnych, konkurencyjności międzyregionalnej i międzynarodowej, handlu, zatrudnienia czy jakości życia. Choć powszechnie przyjmuje się, że inwestycje infrastrukturalne istotnie wpływają na rozwój gospodarczy i są tym samym jednym z najważniejszych narzędzi polityki rozwoju, to dotychczasowe badania naukowe i dyskusje ekspertów wskazują na mniej jednoznaczne wnioski. $Z$ jednej strony wiele analiz potwierdza związek przyczynowo-skutkowy pomiędzy inwestycjami publicznymi a wzrostem i rozwojem gospodarczym, poprzez różne parametry je definiujące, z drugiej jednak strony część badań nie przynosi tak silnych dowodów na poparcie tej tezy. Wynika to po części z problemów metodologicznych i różnych podejść badawczych, co jest podkreślane w literaturze.

Problem roli inwestycji publicznych w gospodarce jest istotny dla działalności inwestycyjnej gminy, ponieważ jako podstawowa jednostka samorządu terytorialnego ma ona realny wpływ na kształtowanie warunków życia i prowadzenia działalności gospodarczej na podległym sobie terenie i to na niej spoczywają zadania związane z lokalną infrastrukturą techniczną i społeczną. Teoretycznym uzasadnieniem zaangażowania gmin w inwestycje infrastrukturalne (podobnie jak innych jednostek sfery publicznej) jest koncepcja zawodności rynku, w tym fakt istnienia dóbr publicznych i efektów zewnętrznych oraz przekonanie o korzyściach wynikających z rozwoju infrastruktury publicznej dla pobudzania rozwoju gospodarczego. Nie można również zapomnieć o teorii administracji publicznej, w której patrzy się na rolę władz gminy z perspektywy prawnoustrojowej (organizacyjnej), według której samorząd terytorialny jest tworzony w celu sprawowania w wyznaczonym 
zakresie administracji państwowej i ochrony interesu lokalnego. Dochodzimy tu do podstawy formalnej występowania gminy w roli inwestora realizującego inwestycje infrastrukturalne. Są nią ustawowo przypisane gminom zadania, w większości dotyczące spraw mieszczących się w sferze polityki inwestycyjnej i wymagające od gminy podejmowania inwestycji rzeczowych $w$ infrastrukturę lokalną.

Polityka inwestycyjna gmin jest elementem ogólnej polityki rozwoju. Paradygmat rozwoju społeczno-gospodarczego, który wyznacza cele gminnej polityki, oparty został na koncepcji zrównoważonego rozwoju. Zrównoważony rozwój społeczno-gospodarczy powinien dokonywać się na drodze poszukiwania optymalnych rozwiązań pomiędzy często sprzecznymi celami, jakimi są wzrost gospodarczy, poprawa jakości życia w skali społecznej i jednostkowej w powiązaniu z zachowaniem równowagi i trwałości ekosystemu [Matysiak i Struś 2015]. Warto w tym miejscu zaznaczyć, że ogólne założenia zrównoważonego rozwoju zostały wprowadzone do różnych obszarów funkcjonalnych i sektorów gospodarki, w tym rolnictwa. Dlatego też polityka rozwoju społeczno-gospodarczego w kontekście zasad zrównoważonego rozwoju musi odpowiadać potrzebom i możliwościom danego terytorium lokalnego. Wpisując politykę inwestycyjną gmin w cele polityki zrównoważonego rozwoju społeczno-gospodarczego, należy podkreślić zasadniczą rolę inwestycji infrastrukturalnych w tym względzie.

Rola gmin w polityce inwestycyjnej realizuje się przede wszystkim przez planowanie i realizacjęi inwestycji infrastrukturalnych. Efektem tych działań są obiekty lokalnej infrastruktury technicznej i społecznej służące świadczeniu usług publicznych na rzecz społeczności lokalnej. Lokalna infrastruktura techniczna służy zarówno wspieraniu działalności gospodarczej podmiotów, stwarzając warunki do realizacji przedsięwzięć gospodarczych, jak i umożliwia zaspokojenie potrzeb społeczności lokalnej w zakresie dostaw mediów, utrzymania czystości czy dostępu do komunikacji lokalnej i gminnej sieci drogowej. Lokalna infrastruktura społeczna obejmuje swoim zakresem obiekty związane z działalnością opiekuńczo-wychowawczą, szkolno-edukacyjną, kulturalną, sportowo-rekreacyjną, ochroną zdrowia i opieką medyczną. Choć przyjmuje się, że jej znaczenie dla działalności gospodarczej i inwestycji prywatnych jest zdecydowanie mniejsze niż infrastruktury technicznej, co wynika z pełnionych przez nią funkcji, to nie można pominąć jej roli aktywizującej rozwój gospodarczy.

\section{Rola gminy w odpowiedzialnym inwestowaniu}

Nawiązując do definicji podanej we wcześniejszej części pracy, inwestycje społecznie odpowiedzialne są formą inwestowania środków indywidualnych lub instytucjonalnych w celu pozyskania zarówno korzyści ekonomicznych, jak 
i korzyści społecznych, przy uwzględnieniu wymogów etycznych, w myśl idei zrównoważonego rozwoju. Inwestycje społecznie odpowiedzialne cechuje dbałość o relacje pomiędzy poszczególnymi grupami interesariuszy oraz troska o środowisko naturalne w długim horyzoncie czasowym.

Wraz z rozwojem gospodarki rynkowej istotnym przeobrażeniom uległa działalność samorządów lokalnych. Wyraźnie widoczna jest zmiana w zakresie aktywności inwestycyjnej jednostek samorządu terytorialnego podejmowanej w celu poprawy wizerunku danego obszaru, tak aby zmieniło się jego postrzeganie prez mieszkańców, turystów czy inwestorów. Samorządy stały się swego rodzaju podmiotem gospodarczym zmuszonym do wolnorynkowej rywalizacji. Rywalizacja ta tym różni się od działalności tradycyjnych podmiotów gospodarczych, że ograniczona jest szczególnymi uwarunkowaniami prawnymi, finansowymi i społecznymi, ale w przeciwieństwie do przedsiębiorstw prywatnych jednostki samorządu terytorialnego zostały prawnie wyposażone w dodatkowe narzędzia ułatwiające im działalność inwestycyjną.

Realizowane inwestycje gminne powinny służyć przede wszystkim społeczności lokalnej. Efektami podejmowanych działań inwestycyjnych są korzyści społeczne odczuwalne w długim okresie, np. poprawa warunków mieszkaniowych na skutek poprawy jakości dróg, rozbudowy sieci uzbrojenia terenu, utrzymania czystości w gminie, czy choćby poprawa bezpieczeństwa, warunków edukacyjnych czy warunków zdrowotnych mieszkańców. Ze względu na istotę działalności inwestycyjnej gmin koszty i korzyści polityki inwestycyjnej oraz określonych projektów infrastrukturalnych nie są oceniane wyłącznie w kategoriach ekonomicznych, ale także przez pryzmat skutków społecznych i środowiskowych.

W świetle definicji przytoczonych w pierwszej części pracy sam społeczny charakter inwestycji gminnych nie czyni z nich jeszcze inwestycji odpowiedzialnych społecznie. Korzyści społeczne są bowiem osiągane z racji ich celu inwestycyjnego, bez względu na sposób przygotowania i realizacji tych działań, w przeciwieństwie do inwestycji społecznie odpowiedzialnych. W myśl idei odpowiedzialnego inwestowania wszelkie inwestycje gminne powinny być, we wszystkich fazach procesu inwestycyjnego, skupione na poszanowaniu praw człowieka, praw pracowniczych, ochronie środowiska, jak również relacjach z wszystkimi interesariuszami tego procesu inwestycyjnego i przyszłymi użytkownikami inwestycji.

Inwestycje infrastrukturalne, zarówno w zakresie infrastruktury technicznej, jak i społecznej, prowadzone na obszarze gminy mogą być realizowane przez różnorodne podmioty. Uwzględniając kryterium podmiotowe, inwestycje realizowane w gminie można podzielić na pięć zasadniczych rodzajów [Zimny 2008, s. 32 i nast.]:

- inwestycje w zakresie realizacji zadań własnych gminy, w których głównym inwestorem jest gmina, ponosząca przez cały proces inwestycyjny w pełni odpowiedzialność za realizację inwestycji, 
- inwestycje realizowane przez gminę wspólnie z innymi jednostkami samorządu terytorialnego i (lub) ze Skarbem Państwa,

- inwestycje w zakresie partnerstwa publiczno-prywatnego, w których gmina podejmuje współpracę z prywatnym podmiotem gospodarczym $\mathrm{w}$ celu realizacji projektów inwestycyjnych,

- inwestycje realizowane na terenie danej gminy przez inwestorów prywatnych niezwiązanych organizacyjnie i kapitałowo z gminą;

- inwestycje realizowane wspólnie ze społecznością lokalną.

Gmina nie jest jedynym podmiotem realizującym inwestycje infrastrukturalne. Jej zaangażowanie w realizację poszczególnych przedsięwzięć inwestycyjnych jest zróżnicowane i uwarunkowane przede wszystkim celem inwestycyjnym, sposobem finansowania, regulacjami prawnymi czy stopniem zaangażowania innych podmiotów (np. przedsiębiorców, społeczności lokalnej). Z jednej strony gmina czynnie uczestniczy w procesie inwestycyjnym jako inwestor lub współinwestor, z drugiej - jest propagatorem rozwiązań w zakresie odpowiedzialnych inwestycji. Aktywność inwestycyjna staje się wtedy ograniczona wyłącznie do roli kreatora warunków inwestycyjnych w obszarze gminy i umożliwiania realizacji inwestycji innym podmiotom. W obu przypadkach gmina jest gospodarzem terenu, na którym inwestycje są realizowane, co powoduje, że zawsze staje się ona interesariuszem prowadzonych inwestycji infrastrukturalnych.

Mając na uwadze aktywność gminy w zakresie realizacji inwestycji wspierających rozwój lokalny zgodny z koncepcją zrównoważonego rozwoju, można wskazać najważniejsze zadania gminy w zakresie przygotowania i realizacji inwestycji (tabela 1).

Tabela 1. Obszary aktywności gminy w procesie odpowiedzialnego inwestowania

\begin{tabular}{|l|l|}
\hline $\begin{array}{l}\text { Obszary aktywności } \\
\text { gminy }\end{array}$ & \multicolumn{1}{c|}{ Charakterystyka } \\
\hline $\begin{array}{l}\text { Badanie potrzeb } \\
\text { inwestycyjnych }\end{array}$ & $\begin{array}{l}\text { Badanie z uwzględnieniem potrzeb mieszkańców gminy i inwestorów, } \\
\text { ale także innych interesariuszy (np. instytucji publicznych, turystów, } \\
\text { partnerów zagranicznych) }\end{array}$ \\
\hline $\begin{array}{l}\text { Definiowanie doku- } \\
\text { mentów strategicz- } \\
\text { nych }\end{array}$ & $\begin{array}{l}\text { Definiowanie dokumentów (np. strategia rozwoju gminy, plany inwesty- } \\
\text { cyjne, studium uwarunkowań i kierunków zagospodarowania przestrzen- } \\
\text { nego, miejscowy plan zagospodarowania przestrzennego, programy } \\
\text { rewitalizacyjne) ze szczególnym uwzględnieniem potrzeb ekonomicz- } \\
\text { nych, społecznych i środowiskowych gminy i jej mieszkańców }\end{array}$ \\
\hline $\begin{array}{l}\text { Wyznaczenie obiek- } \\
\text { tywnych kryteriów } \\
\text { wyboru inwestycji }\end{array}$ & $\begin{array}{l}\text { Wyznaczenie kryteriów w zależności od spodziewanych efektów ekono- } \\
\text { micznych, społecznych i środowiskowych przy uwzględnieniu istnieją- } \\
\text { cych ograniczeń zasobowych }\end{array}$ \\
\hline
\end{tabular}


cd. tabeli 1

\begin{tabular}{|c|c|}
\hline $\begin{array}{l}\text { Obszary aktywności } \\
\text { gminy }\end{array}$ & Charakterystyka \\
\hline $\begin{array}{l}\text { Hierarchizacja } \\
\text { potrzeb inwestycyj- } \\
\text { nych }\end{array}$ & $\begin{array}{l}\text { Hierarchizacja potrzeb ze szczególnym uwzględnieniem potrzeb ekono- } \\
\text { micznych, społecznych i środowiskowych gminy i jej mieszkańców, } \\
\text { zgodnie z przyjętym kierunkiem rozwoju gminy }\end{array}$ \\
\hline $\begin{array}{l}\text { Określenie stan- } \\
\text { dardów realizacji } \\
\text { inwestycji }\end{array}$ & $\begin{array}{l}\text { Standardy realizacji inwestycji obejmują m.in.: } \\
\text { - zasady oceny spójności inwestycji z potrzebami społecznymi i kierun- } \\
\text { kami rozwoju gminy określonymi w dokumentach strategicznych } \\
\text { - zasady wyboru lokalizacji (uwzględniające m.in. wykorzystanie tere- } \\
\text { nów poprzemysłowych, zdegradowanych, wymagających rewitalizacji) } \\
\text { - zasady pozyskiwania gruntów inwestycyjnych z poszanowaniem prawa } \\
\text { własności (np. wykorzystanie terenów publicznych, wykonywanie } \\
\text { prawa pierwokupu, realizacja procedury scalenia i podziału potencjal- } \\
\text { nych terenów inwestycyjnych) } \\
\text { - zasady współpracy z partnerami, wykonawcami i podwykonawcami, } \\
\text { z uwzględnieniem m.in. zasad równego traktowania, uczciwej kon- } \\
\text { kurencji i praw pracowniczych (wprowadzanie klauzul społecznych } \\
\text { do procedur przetargowych) } \\
\text { - zasady ustalania dodatkowych wymogów dotyczących realizowanych } \\
\text { inwestycji (np. w zakresie dostępności terenów rekreacyjnych, obiek- } \\
\text { tów użyteczności publicznej, zaplecza parkingowego) } \\
\text { - pożądane parametry techniczne wznoszonych obiektów budowlanych } \\
\text { zgodne z wymogami zrównoważonego budownictwa (m.in. w zakresie } \\
\text { energochłonności, wykorzystania odnawialnych źródeł energii, emisji } \\
\text { szkodliwych gazów, ergonomii powierzchni, alternatywnej funkcji } \\
\text { obiektu) } \\
\text { - zasady wykonywania prac inwestycyjnych z uwzględnieniem dbałości } \\
\text { o bezpieczeństwo pracowników, poszanowania potrzeb użytkowników } \\
\text { terenów przyległych oraz troski o środowisko naturalne (ze wskaza- } \\
\text { niem działań kompensacyjnych) }\end{array}$ \\
\hline $\begin{array}{l}\text { Określenie stan- } \\
\text { dardów obsługi } \\
\text { inwestora }\end{array}$ & $\begin{array}{l}\text { Standardy obsługi inwestora obejmują m.in.: } \\
\text { - zasady oceny inwestycji zgodnie z przyjętymi w gminie standardami } \\
\text { - zasady udzielania wsparcia inwestorom w zakresie pozyskiwania } \\
\text { i przygotowania gruntów inwestycyjnych, poprawy stanu infrastruk- } \\
\text { tury technicznej i komunikacyjnej, ze szczególnym uwzględnieniem } \\
\text { potrzeb społecznych i kierunków rozwojowych gminy } \\
\text { - zasady udzielania zachęt inwestycyjnych (np. ulgi podatkowe, zmniej- } \\
\text { szanie opłat, ułatwienia organizacyjno-administracyjne) dla inwestorów } \\
\text { - zasady obsługi inwestora w gminie (w tym również inwestora zagra- } \\
\text { nicznego) }\end{array}$ \\
\hline $\begin{array}{l}\text { Stałe informowanie } \\
\text { mieszkańców }\end{array}$ & $\begin{array}{l}\text { Informowanie mieszkańców o planowanych, realizowanych i zakończo- } \\
\text { nych inwestycjach w gminie }\end{array}$ \\
\hline $\begin{array}{l}\text { Ocena zrealizowanej } \\
\text { inwestycji }\end{array}$ & $\begin{array}{l}\text { Ocena inwestycji pod względem potrzeb ekonomicznych, społecznych } \\
\text { i środowiskowych gminy i jej mieszkańców, zgodnie z przyjętym kierun- } \\
\text { kiem rozwoju gminy }\end{array}$ \\
\hline
\end{tabular}

Źródło: opracowanie własne. 
Działalność inwestycyjna gminy uregulowana jest wieloma przepisami prawnymi ustalanymi na szczeblu centralnym. Wskazują one zasadnicze obszary działalności gminy oraz wyposażają ją w odpowiednie narzędzia. Przepisy te jednak nie narzucają szczegółowych rozwiązań w zakresie definiowania kierunków rozwoju gminy czy ustalania zasad realizacji i obsługi lokalnych inwestycji tu istotną rolę odgrywają rozwiązania prawne przyjęte na szczeblu lokalnym, w drodze gminnych uchwał, zarządzeń czy dokumentów strategicznych. Tworząc regulacje lokalne, gminy stają się uprawnione do określenia własnych standardów realizacji i obsługi inwestycji, w zgodzie z miejscowymi uwarunkowaniami społecznymi, środowiskowymi i ekonomicznymi.

Stosowanie zasad społecznej odpowiedzialności przez samorządy terytorialne może przynosić wiele korzyści. Wśród najważniejszych wymienić należy m.in.: możliwość jawnego przekazywania mieszkańcom, inwestorom, turystom czy partnerom zagranicznym informacji o postępach w istotnych obszarach działalności, budowanie kapitału społecznego, rozumianego jako zaufanie do instytucji publicznych i społecznych, ograniczanie ryzyka wystąpienia negatywnych zjawisk, zapewnienie wysokiego standardu świadczonych usług, poprawa wizerunku administracji publicznej [Raportowanie niefinansowe... 2015].

Niewątpliwie największa aktywność gminy w zakresie realizacji lub obsługi inwestycji społecznie odpowiedzialnych widoczna jest na wstępnym etapie inwestycji, czyli w tzw. fazie przedinwestycyjnej. Wraz z konkretyzacją projektu inwestycyjnego maleje wpływ gminy na charakter całej inwestycji i tym samym ograniczony staje się wpływ gminy na osiągane korzyści społeczne, gospodarcze i środowiskowe.

\section{Przyczyny i konsekwencje nieodpowiedzialnego inwestowania gmin}

Choć odpowiedzialne społecznie inwestowanie jest podejściem pożądanym i wpisanym w istotę działalności takich jednostek publicznych jak gmina, to powszechnie opisywane przypadki nieudanych przedsięwzięć inwestycyjnych wskazują na potrzebę bliższego przyjrzenia się temu problemowi ${ }^{3}$. Nie sposób wskazać wszystkich możliwych przyczyn błędów popełnianych w procesie inwe-

${ }^{3} \mathrm{~W}$ prasie opisywanych jest wiele przykładów nieudanych inwestycji finansowanych ze środków publicznych (http://www.newsweek.pl/polska/chybione-inwestycje-w-gminach-za-dotacje-ue,88530,1,1.html, data dostępu: 28.06.2017). Najczęściej pojawiającymi się problemami są: nieuzasadnione rzeczywistymi potrzebami społecznymi i przeczące zasadom racjonalności realizowane koncepcje inwestycyjne, brak środków finansowych na dokończenie inwestycji oraz ich utrzymanie w fazie eksploatacji (zob. [Piasek 2013]). 
stowania gmin, gdyż mają one wiele źródeł i są to z reguły zagadnienia złożone. Można jednak wyodrębnić kilka znaczących obszarów problemowych tworzących bariery odpowiedzialnego inwestowania. Należą do nich m.in.:

- ułomny system planowania przestrzennego gmin, w wyniku którego jedynie średnio ok. $29 \%{ }^{4}$ powierzchni kraju pokryte jest planami miejscowymi, z czego nie wszystkie istniejące plany dobrze spełniają swoje funkcje (zob. [System gospodarowania... 2017]),

- niewłaściwy i nieefektywny sposób przeprowadzania konsultacji społecznych, szczególnie pod względem ich przygotowania i późniejszej ewaluacji, momentu przeprowadzania (zwykle na zbyt zaawansowanym etapie decyzyjnym), oraz brak faktycznego ich wpływu na wybory i decyzje organów (zob. [Raport końcowy... 2011a]),

- błędnie rozumiana konkurencja pomiędzy gminami w zakresie działalności inwestycyjnej i wykorzystania funduszy unijnych,

- brak ciągłości w planowaniu i realizacji polityki inwestycyjnej, która może stać się narzędziem budowania kapitału politycznego rządzących,

- niestabilność sytuacji finansowej gmin, niedostosowanie planów inwestycyjnych do możliwości finansowych (zob. np. [Wykonywanie zadań... 2016] i dostępności innych niezbędnych zasobów, w tym zasobów gruntowych,

- brak współpracy pomiędzy gminami przy realizacji kapitałochłonnych inwestycji [Zimny 2008, s. 123 i inne], ograniczony udział partnerstwa publiczno-prywatnego w inwestycjach publicznych ${ }^{5}$,

- niewystarczające wsparcie ekspertów w procesie merytorycznej ewaluacji i przygotowania do realizacji projektów inwestycyjnych,

- słabe powiązanie działalności inwestycyjnej z instrumentami przewidzianymi w ramach gospodarki nieruchomościami, w tym m.in. brak aktywnego i perspektywicznego kształtowania gminnych zasobów gruntowych [Zimny 2008, s. 42], stanowiących „bank ziemi” przydatnej pod przyszłą działalność inwestycyjną,

- wady istniejącego ustawodawstwa, w tym wiele teoretycznie przydatnych narzędzi będących w praktyce instrumentami „,martwymi”, czego przykładem jest procedura scaleń i podziałów czy stosowanie opłat planistycznych i adiacenckich [Ustalanie... 2013].

Zarówno wymienione bariery, jak i wiele innych barier prowadzi do skutków, które przekładają się na ocenę efektywności i trafności zrealizowanych projektów inwestycyjnych. Efekty błędnych podstaw decyzji inwestycyjnych czy wadliwego

${ }^{4}$ Wartość określona na podstawie wyliczeń własnych autorów opartych na danych Banku Danych Lokalnych GUS.

${ }^{5} \mathrm{Na}$ ograniczony zakres stosowania formuły PPP w realizacji inwestycji publicznych wskazuje się w wielu opracowaniach, zob. np. [Realizacja przedsięwzięć... 2013, Postrzeganie partnerstwa... 2016]. 
ich wdrożenia dostrzegalne są zarówno w sferze społecznej, finansowej, ekonomicznej, jak i przestrzenno-środowiskowej.

Po stronie skutków społecznych można wymienić niezadowolenie mieszkańców wynikające z braku zaspokojenia odczuwanych, ważnych potrzeb społecznych i zaniechania inwestycji kluczowych dla mieszkańców niejednokrotnie na rzecz inwestycji istotnych dla włodarzy (spełniających ich osobiste aspiracje). Poczucie bycia lekceważonymi skutkuje spadkiem zaangażowania społecznego, w sytuacji gdy tzw. dialog społeczny był prowadzony w sposób pozorny, bez rzeczywistego przełożenia na przyszłe działania.

Po stronie skutków finansowych, które mają odbicie zarówno w sferze majątkowej, jak i społecznej, należy przede wszystkim wymienić problem inwestycji nieukończonych i opóźnionych z powodu braku finansowania, obiektów nieużytkowanych z uwagi na brak środków na ich utrzymanie i prowadzenie działalności operacyjnej oraz narastający dług publiczny gmin prowadzący do podnoszenia obciążeń w postaci podatków i opłat lokalnych na pokrycie dziury budżetowej.

Skutki przestrzenno-środowiskowe mają źródło m.in. w chaotycznej i rozlewającej się zabudowie, realizowanej przez inwestorów prywatnych na podstawie doraźnie wydawanych decyzji o warunkach zabudowy przy braku planów miejscowych. Problem ten występuje głównie w gminach miejskich, co prowadzi do dalszych, szeroko rozumianych konsekwencji. Ponadto wadliwie lokalizowane i realizowane inwestycje mogą ograniczać przestrzeń publiczną, zmniejszać dostęp do terenów zielonych czy wywoływać negatywne skutki dla środowiska naturalnego i otoczenia.

Podsumowując, brak społecznej odpowiedzialności w inwestycjach publicznych w dłużej perspektywie prowadzi do obniżenia atrakcyjności gminy jako miejsca zamieszkania i prowadzenia działalności gospodarczej oraz zmniejsza szanse na zrównoważony rozwój terytorium lokalnego.

\section{Podsumowanie}

Realizacja inwestycji społecznie odpowiedzialnych wymaga aktywności samorządu gminnego wykraczającej poza wymogi przepisów i procedur. Bez względu na podmiot inwestujący gmina zawsze uczestniczy w procesie inwestycyjnym z jednej strony występuje jako bezpośredni inwestor, a z drugiej jako gospodarz terenu kreujący warunki inwestycyjne. Obie te role ostatecznie wpływają na kształt przestrzeni lokalnej i tworzą podstawy bądź bariery zrównoważonego rozwoju.

W artykule wskazano główne obszary zaangażowania gmin na rzecz społecznie odpowiedzialnego inwestowania, zarówno w odniesieniu do własnej polityki inwestycyjnej, jak i do innych podmiotów realizujących inwestycje w obrębie gminy. 
Wyróżniono sferę przygotowania, realizacji i obsługi inwestycji oraz wskazano główne zadania i wymogi z nimi związane, w tym badanie i hierarchizację potrzeb inwestycyjnych, definiowanie dokumentów strategicznych, określanie kryteriów wyboru inwestycji oraz standardów ich realizacji i oceny.

Należy podkreślić, że szczególną rolę w procesie odpowiedzialnego inwestowania odgrywa społeczność lokalna - zwłaszcza w diagnozowaniu potrzeb i planowaniu inwestycji publicznych, które powodują wyraźne i długotrwałe zmiany w układzie przestrzenno-środowiskowym gminy, wpływając na obecną i przyszłą jakość życia mieszkańców.

Realizacja inwestycji zgodnie z ideą odpowiedzialnego inwestowania z pewnością stanowi wyzwanie dla urzędników, którzy muszą stawić czoła wielu uciążliwościom. W praktyce nie wszystkie zapoczątkowane czy zrealizowane inwestycje oceniane są pozytywnie. Studia przypadków oraz opublikowane przez różne instytucje wyniki badań i ekspertyz pozwoliły wskazać zasadnicze obszary problemowe utrudniające implementację idei odpowiedzialnego inwestowania w sektorze inwestycji publicznych i prowadzące do negatywnych zjawisk i ich skutków odczuwalnych w sferze społecznej, gospodarczej i przestrzenno-środowiskowej.

\section{Literatura}

Aschauer D.A. [1989a], Is Public Expenditure Productive?, „, Journal of Monetary Economics", vol. 23, nr 2, https://doi.org/10.1016/0304-3932(89)90047-0.

Aschauer D.A. [1989b], Public Investment and Productivity Growth in the Group of Seven, „Economic Perspectives”, Federal Reserve Bank of Chicago, vol. 13, nr 5.

Aschauer D.A. [1990a], Highway Capacity and Economic Growth, „Economic Perspectives", Federal Reserve Bank of Chicago, vol. 14, nr 5.

Aschauer D.A. [1990b], Is Government Spending Stimulative?, „Contemporary Economic Policy", vol. 8, nr 4, https://doi.org/10.1111/j.1465-7287.1990.tb00300.x.

Aschauer D.A. [1990c], Why Is Infrastructure Important?, Conference Series (Proceedings), Federal Reserve Bank of Boston, vol. 34.

Brodowicz D.P. [2014], Odpowiedzialne inwestowanie na rynku nieruchomości w Polsce, bariery i możliwości dla inwestorów, Oficyna Wydawnicza Szkoła Główna Handlowa w Warszawie, Warszawa.

Calderon C., Servén L. [2004], The Effects of Infrastructure Development on Growth and Income Distribution, Policy Research Working Paper 3400, World Bank, https://doi.org/ 10.1596/1813-9450-3400.

Duffy-Deno K.T., Randall W.E. [1991], Public Infrastructure and Regional Economic Development: A Simultaneous Approach, ,Journal of Urban Economics”, vol. 30, nr 3, https://doi.org/10.1016/0094-1190(91)90053-A.

Duliniec A. [2015], Inwestowanie społecznie odpowiedzialne - przejściowa moda czy trwała tendencja?, Zeszyty Naukowe Uniwersytetu Ekonmicznego w Krakowie, nr 1(937), https://doi.org/10.15678/ZNUEK.2015.0937.0103. 
Gil N., Beckman S. [2009], Infrastructure Meets Business: Building New Bridges, Mending Old Ones, ,California Management Review”, vol. 51, nr 2, https://doi.org/10.2307/41166478.

Jonker J., Rudnicka A., Reichel J. [2011], Nowe horyzonty. Przewodnik po społecznej odpowiedzialności i rozwoju zrównoważonym, Centrum Strategii i Rozwoju Impact, Łódź.

Kessides C. [1993], The Contributions of Infrastructure to Economic Development. A Rewiew of Experience and Policy Implications, no. 213, Discussion Papers, World Bank, https://doi.org/10.1596/0-8213-2628-7.

Lewicka-Strzałecka A. [2006], Odpowiedzialność moralna w życiu gospodarczym, IFiS PAN, Warszawa.

Marcinek K. [2012], Społecznie odpowiedzialne inwestowanie na rynku nieruchomości [w:] „Studia Ekonomiczne”, nr 104 Inwestycje i nieruchomości: wybrane zagadnienia, Uniwersytet Ekonomiczny w Katowicach, http://www.ue.katowice.pl/fileadmin/_ migrated/content_uploads/SE_104.pdf (data dostępu: 28.06.2017).

Matysiak A., Struś M. [2015], Paradygmat rozwoju zrównoważonego, „Studia Ekonomiczne. Zeszyty Naukowe Uniwersytetu Ekonomicznego w Katowicach”, nr 213.

Munnell A.H. [1992], Policy Watch. Infrastructure Investment and Economic Growth, „Journal of Economic Perspective”, vol. 6, nr 4, https://doi.org/10.1257/jep.6.4.189.

Munnell A.H., Cook L.M. [1990], How Does Public Infrastructure Affect Regional Economic Performance?, ,New England Economic Review”, issue Sep.

Odpowiedzialne inwestowanie [2017], Materiały Stowarzyszenia Emitentów Giełdowych, http://seg.org.pl/pl/node/2129 (data dostępu: 21.05.2017).

Piasek W. [2013], Nietrafione podkarpackie inwestycje za pieniqudze unijne, http://www. biznesistyl.pl/biznes/biznes-na-co-dzien/1444_nietrafione-podkarpackie-inwestycje-za-pieniadze-unijne.html (data dostępu: 28.06.2017).

Postrzeganie partnerstwa publiczno-prywatnego przez przedstawicieli instytucji publicznych. Raport z badania [2016], https://www.ppp.gov.pl/Aktualnosci/Documents/Analiza_postrzegania_PPP.pdf (data dostępu: 28.06.2017).

Raport końcowy z badania efektywności mechanizmów konsultacji społecznych [2011a], Badanie zlecone przez Ministerstwo Pracy i Polityki Społecznej „Badania efektywności mechanizmów konsultacji społecznych" realizowane w ramach Programu Operacyjnego Kapitał Ludzki 2007-2013 współfinansowanego przez Unię Europejską w ramach Europejskiego Funduszu Społecznego, http://www.pozytek.gov.pl/files/ Biblioteka/raport_efekt_konsult.pdf (data dostępu: 28.06.2017).

Raport końcowy z badania efektywności mechanizmów konsultacji społecznych [2011b], Pracownia Badań i Innowacji Społecznych Stocznia, Millward Brown SMG/KRC, Warszawa.

Raportowanie niefinansowe. Poradnik dla raportujacych [2015], Opracowanie Zespołu ds. Społecznej Odpowiedzialności Przedsiębiorstw, CSRinfo, http://www.csrinfo.org/ poradnik-dla-raportujacych-raportowanie-niefinansowe (data dostępu: 28.06.2017).

Ratajczak M. [2000], Infrastruktura a wzrost i rozwój gospodarczy, „Ruch Prawniczy, Ekonomiczny i Socjologiczny", LXII/4.

Realizacja przedsięwzięć $w$ systemie partnerstwa publiczno-prywatnego [2013], Najwyższa Izba Kontroli, nr ewid. 1/2013/P/12/051/KGP, https://www.nik.gov.pl/plik/ id,4883,vp,6353.pdf (data dostępu: 28.06.2017).

Recommendation of the Council on Effective Public Investment Across Levels of Government [2014], OECD, March 12. 
Rives J.M., Heaney M.T. [1995], Infrastructure and Local Economic Development, „Journal of Monetary Economics", vol. 25, nr 1.

Rok B. [2008], Biznes społecznie odpowiedzialny - teoria i praktyka [w:] Ekonomia społeczna a rozwój, red. J. Hausner, www.ekonomiaspoleczna.msap.pl/Skrypty/es\%20 skrypt1.pdf (data dostępu: 28.06.2017).

Ślęzak-Gładzik I. [2013], Społeczna odpowiedzialność w ujęciu normy międzynarodowej ISO 26000 Guidance on Social Responsibility, „Modern Management Review”, vol. XVIII, 20 (4/2013).

Standardy obsługi inwestorów w Małopolsce, www.fundusze20072013.malopolska.pl (data dostępu: 27.04.2017).

System gospodarowania przestrzeniq gminy jako dobrem publicznym. Zbiorcze zestawienie kontroli przeprowadzonych pod katem gospodarowania przestrzeniq [2017], Najwyższa Izba Kontroli, nr ewid. 193/2016/KIN, https://www.nik.gov.pl/plik/ id,13219,vp,15636.pdf (data dostępu: 28.06.2017).

Ustalanie i egzekwowanie przez gminy województwa warmińsko-mazurskiego opłaty adiacenckiej oraz opłaty planistycznej [2013], Najwyższa Izba Kontroli, nr ewid. 5/2013/12/156/LOL, https://www.nik.gov.pl/kontrole/P/12/156/LOL/ (data dostępu: 28.06.2017).

Wolska M., Czerwonka M. [2013], Społecznie odpowiedzialne inwestowanie - analiza rentowności funduszy SRI w Polsce, Studia i Prace Kolegium Zarządzania i Finansów, Zeszyt Naukowy 126, SGH, Warszawa.

Wpływ czynników ESG na decyzje inwestycyjne [2016], Raport z badania przeprowadzonego przez Giełdę Papierów Wartościowych w Warszawie oraz firmę doradczą Deloitte, Warszawa, https://www2.deloitte.com/content/dam/Deloitte/pl/Documents/ Reports/pl_Raport_decyzje_inwestycyjne_13102016.pdf (data dostępu: 21.05.2017).

Wykonywanie zadań regionalnych izb obrachunkowych $w$ zakresie przeciwdziatania zagrożeniom wynikajqcym z nadmiernego zadtużania się jednostek samorzqdu terytorialnego [2016], Najwyższa Izba Kontroli, nr ewid.18/2015/14/066/LBI, https://www. nik.gov.pl/plik/id,8484,vp,10578.pdf (data dostępu: 28.06.2017).

Zimny A. [2008], Uwarunkowania efektywności inwestycji gminnych w sferze infrastruktury technicznej, Państwowa Wyższa Szkoła Zawodowa w Koninie, Konin.

\section{Pro-development Investments of Municipalities and the Concept of Socially Responsible Investment}

(Abstract)

The article discusses the engagement of local governments in socially responsible investment. Due to the goals and tasks taken by municipalities in the area of investment policy, which is a crucial part of general local development policy, there is a need to ask: In what sense do municipal authorities contribute to socially responsible investments and support the sustainable development of local areas?

This issue is considered in relation to the municipality's own investment and to investment undertaken by other entities in municipalities. In their conclusions, the authors emphasize the key circumstances that reflect municipalities' contribution to public and private socially responsible investments, mainly in the following areas: analysing and 
locating investment needs on a hierarchy, defining strategic documents, establishing selection criteria and standards for implementing and evaluating investments. Finally, the article presents the main causes and consequences of municipal investment activities, which stand in contrast to the idea of responsible investment.

Keywords: socially responsible investment, sustainable development, local investment, public infrastructure, local development, municipality. 